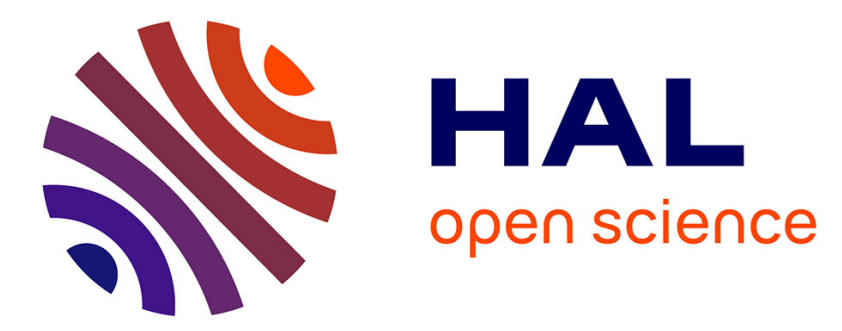

\title{
Local and regional trends in the ground vegetation of beech forests
}

\author{
Arnault Lalanne, Jacques Bardat, Fouzia Lalanne-Amara, Jean-François \\ Ponge
}

\section{- To cite this version:}

Arnault Lalanne, Jacques Bardat, Fouzia Lalanne-Amara, Jean-François Ponge. Local and regional trends in the ground vegetation of beech forests. Flora, 2010, 205 (7), pp.484-498. 10.1016/j.flora.2009.12.032 . hal-00504077

\section{HAL Id: hal-00504077 \\ https://hal.science/hal-00504077}

Submitted on 19 Jul 2010

HAL is a multi-disciplinary open access archive for the deposit and dissemination of scientific research documents, whether they are published or not. The documents may come from teaching and research institutions in France or abroad, or from public or private research centers.
L'archive ouverte pluridisciplinaire HAL, est destinée au dépôt et à la diffusion de documents scientifiques de niveau recherche, publiés ou non, émanant des établissements d'enseignement et de recherche français ou étrangers, des laboratoires publics ou privés. 


\section{Local and regional trends in the ground vegetation of beech forests}

2

3 Arnault Lalanne ${ }^{1}$, Jacques Bardat ${ }^{2}$, Fouzia Lalanne-Amara ${ }^{1}$, Jean-François Ponge ${ }^{1}$ *

4

$5 \quad{ }^{1}$ Muséum National d'Histoire Naturelle, CNRS UMR 7179, 4 avenue du Petit-Château, 91800

6 Brunoy, France; e-mail ponge@mnhn

$7 \quad{ }^{2}$ Muséum National d'Histoire Naturelle, CNRS UMR 7205, 57 rue Cuvier, Case Postale 39,

875231 Paris Cédex 05, France

9

$10 *$ Corresponding author

11

12 E-mail addresses of the authors:

13

14 A. Lalanne, F. Lalanne-Amara: lalanne@mnhn.fr

15 J. Bardat: $\underline{\text { bardat@mnhn.fr }}$

16 J.F. Ponge: ponge@mnhn.fr

17 


\section{Abstract}

2

We sampled moss and vascular forest vegetation in five ancient beech forests from northwest France, embracing in each a wide array of environmental conditions. Indirect (PCA) and direct (RDA) gradient analysis were used to discern local and regional ecological factors which explain the observed variation in species composition. Our results point to a global factor encompassing a large array of soil and light conditions, unravelled when local particularities of studied forests are partialled out. The humus form, numerically expressed by the Humus Index, explains a large part of the observed variation in ground vegetation. Our study confirmed opposite trends in vascular and moss species richness according to humus condition. Ecological factors to which vascular and moss forest species respond at the regional level can be estimated directly on the field by visually inspecting humus forms and vegetation strata despite of the confounding influence of local factors.

Keywords: Beech forests; Ground vegetation; Humus Index; Regional and local factors; Species groups; Species richness

\section{Introduction}

It is widely recognized that forest vegetation varies according to soil fertility and acidity, temperature, light and moisture (Watt, 1934; Ellenberg, 1974; Diekmann and Lawesson, 1999), and is a fairly good indicator of potential growth (Bergès et al. 2006) and ecological integrity (Aubin et al., 2007) of managed forests. It is also admitted that management practices may modify the composition of understory plant communities through their influence on the abovementioned factors (Thomas et al., 1999; Gillet et al., 1999; Van 
1 Calster et al., 2007). Once the ecological requirements of plant species are documented and

2 indexed over wide environmental gradients (Diekmann, 2003), then lists of plant species and

3 their ecograms (Härdtle et al., 2004) can be used to achieve a thorough assessment of site

4 conditions, often in conjunction with humus types (Bartoli et al., 2000; Wilson et al., 2001,

5 but see Wamelink et al., 2002). However, the composition of forest plant communities may

6 also vary locally due to historical heritage (Dupouey et al., 2002; Gachet et al., 2007),

7 dispersal limitation (Bossuyt et al., 1999; Graae and Sunde, 2000; Honnay et al., 2002), biotic

8 interactions (Thompson et al., 1993; Britton et al., 2003; Klanderud and Totland, 2007) and

9 landscape features (Dufour et al., 2006), and thus is in a constant state of change (Wiens, 1984). Among a regional pool, each forest, for past as well as present-day reasons, will select

11 or favour a subsample of species and species traits which will be redistributed according to

12 niche requirements of species, assembly rules and disturbance effects (Keddy, 1992; Zobel, 1997; Rajaniemi et al., 2006). Stable although distinct forest communities may develop on

14 similar sites (McCune and Allen, 1985) as a consequence of attraction domains (Beisner et al., 15 2003).

16

We need tools for disentangling the joint influence of stable and variable environmental factors on vegetation (Ehrenfeld et al., 1997) and to discern environmental gradients of regional importance when plant communities vary locally to a great extent (Ricklefs, 1987; Huston, 1999; Hillebrand, 2005): does the presence of a species indicate the same thing in one and another forest? The present study is an attempt to fulfil this gap within the domain of European beech (Fagus sylvatica L.) forests. For that purpose we selected five ancient forests (Peterken and Game, 1984; Hermy et al., 1999) in Northwest France, where two Atlantic forest habitats, the neutrophile Endymio-Fagetum or EU priority habitat type 41.132 (EUR25, 2003) and the acidiphilous Ilici-Fagetum or EU priority habitat type 41.12 
1 (EUR25, 2003), are well-represented (Bardat, 1993). These beech habitats were described in

2 West and Northwest France as two associations by Durin et al. (1967). We sampled moss and

3 vascular forest vegetation in 995 plots $\left(400 \mathrm{~m}^{2}\right)$ embracing a wide array of canopy,

4 understory, stand age, humus type, soil disturbance, climate and atmospheric deposition

5 conditions. Indirect (PCA) and direct (RDA) gradient analysis were used to discern main local

6 and regional ecological factors which could explain the observed variation in species

7 composition. A particular attention will be given to the humus type, which is both a cause and

8 a consequence of vegetation development (Ponge, 2003; Godefroid et al., 2005) and to which

9 beech forest plant species are highly sensitive (Le Tacon and Timbal, 1973; Falkengren-

10 Grerup and Tyler, 1993; Lalanne et al., 2008).

11

12 Materials and methods

13

14 Study sites

15

Five forests, attested at least from the Roman period (except Compiègne attested from

17 the $14^{\text {th }}$ century only) have been selected in Picardy and Upper Normandy (Table 1). The

18 choice of these forests was dictated by the need to assess the influence of local particularities

19 in the studied region, while remaining in the same plant associations, Endymio-Fagetum (EF)

20 and Ilici-Fagetum (IF) on neutral to acid soils, respectively. All these forests belonged to the

21 royal domain then acquired a national status after the French revolution. After the strong

22 deforestation which occurred during Middle Ages they were submitted to the Forest Law and

23 were managed as coppices-with-standards from $16^{\text {th }}$ to $19^{\text {th }}$ century, then they were

24 progressively converted to full-grown mixed forests. European beech is dominant, but sessile oak (Quercus petraea) or pedunculate oak (Quercus robur) are subordinate or co-dominant in 
1 the canopy. All these lowland forests (altitude $<250 \mathrm{~m}$ ) are established on cretaceous

2 limestone tables of the 'Bassin Parisien'. The calcareous substrate is covered with tertiary and

3 quaternary deposits of varying depth and nature, which were eroded on slopes, providing a

4 variety of strongly acid to alkaline soils. The Brotonne forest is established mainly on a fossil

5 meander of river Seine made up of many quaternary gravel-sand alluvial terraces dated from

6 Riss to Wurm (Quaternary Age). Eawy and Lyons forests occupy especially plates with a

7 thick cover of loess (Quaternary Age). The Compiegne forest is located on a sandy slope

8 (Cuisian stage) and on Sparnacian marls of the alluvial river Oise valley (Tertiary Age). The

9 Retz forest is established on loess (Quaternary Age) and sand (Tertiary Age, Stampian stage)

10 deposits. The annual rainfall decreases and the mean temperature increases from Brotonne

11 and Eawy to Compiègne and Retz, Lyons being intermediate, according to a decreasing

12 Atlantic influence from West to East, without any marked North-South trend (Table 1).

13 Sulphur deposition is higher in Brotonne and Eawy, which are not far from oil refineries

14 located in Le Havre and Rouen, respectively. Nitrogen deposition, mostly of industrial origin

15 in Eawy, and of agricultural origin in Retz, is higher in these two forests. Values reported on

16 Table 1 were interpolated from a national grid of continuous measurements of atmospheric

17 dry deposition, except for Brotonne where measurement was direct (Croisé et al., 2005).

As abovementioned, our study focused on two types of beech habitats, in which beech is associated with holly (Ilex aquifolium) in the understory on most acidic soils (upslope sites

21 with Podzols and Luvisols at $\mathrm{pH}<5$ ) and with bluebell (Hyacinthoides non-scripta) on 22 moderately acidic to neutral soils (downslope sites with Luvisols and Cambisols at $\mathrm{pH}$ between 5 and 7). Both habitats are present in the five studied forests, but their species composition varies locally according to climate and geomorphology. Bardat (1993) described 
1 forest vegetation. Following preliminary investigations, study sites were selected in each

2 forest in order to encompass the widest possible variety of environmental, management and

3 stand age conditions. More sites were sampled in Eawy, the smallest forest investigated, in

4 order to compensate for the relative homogeneity of site conditions. The choice of a non-

5 random selection of forests and stands within forests was dictated by the need to avoid severe

6 biases in the representativeness of sampling sites. More details about the selection of sites

7 according to stand age classes are given in Lalanne (2006).

$9 \quad$ Sampling design and data analysis

At each site five plots $20 \times 20 \mathrm{~m}$, four at angles of a 1 ha square and one at its centre (Lalanne et al. 2008) were surveyed for ground vegetation and environmental factors. In each plot vascular plants (herbs, ferns) and mosses were identified at the species level (Appendix 1) and quantified according to the Braun-Blanquet method. Kerguelen (1993), lastly updated at http://www2.dijon.inra.fr/flore-france/index.htm, was used for the nomenclature of vascular plants, and Hill et al. (2006) for mosses. Species living in aboveground micro-habitats (trunk bases, boulders, dead branches and trunks) were not recorded. Previous to numerical treatment Braun-Blanquet cover-abundance data were transformed in percentage values according to Van der Maarel (1979). Species which were present in less than 10 sample plots were excluded from further analyses, except for the calculation of species richness.

Ellenberg's indices (Light, Wetness, Fertility, pH) were affected to each plant species (Appendix 1). For vascular plant species we used indicator values calculated for the British Isles (Hill et al., 1999). For moss species we used a table prepared by one of us (J.B.), which was partly published in Bardat and Aubert (2007). The Fertility Index was equivalent to the N 
1 ('Stickstoff') index of Ellenberg (1974). Ellenberg's indices were averaged for each plot according to Wamelink and Van Dobben (2003), in order to provide a global assessment of ecological requirements of vegetation units on the base of auto-ecological characters. (1)

Environmental descriptors were recorded at each sampling plot (Appendix 2). Canopy cover, as well as sub-canopy cover and shrub cover when present, were estimated by coverabundance values according to the Braun-Blanquet scale and subsequently transformed into cover percentages as abovementioned. The Humus Index was estimated by scoring humus forms according to Ponge et al. (2002). Four measurements of the Humus Index were averaged after subdividing each $400 \mathrm{~m}^{2}$ plot into four $100 \mathrm{~m}^{2}$ sub-plots, at the centre of which as small pit was dug off. The choice of a regular grid rather than of a random selection of points was due to the combined need for representativeness and minimum digging of the soil. The ground surface was thoroughly observed and classified into several categories of topsoil disturbance and dead wood deposition (Appendix 2), the cover percentage of which was estimated visually in each plot. For the need of calculation, categories of topsoil disturbance were pooled into gross categories (undisturbed $=$ Surf1, weak disturbance $=$ Surf2 to Surf8, severe disturbance $=$ Surf9 to Surf14). Stem density and basal area were estimated by counting and measuring the diameter at breast height $(\mathrm{DBH})$ of all trees and shrubs with a stem diameter higher than $7.5 \mathrm{~cm}$. The age of dominant trees (crowns extending above the general level of the canopy) was estimated by classifying them into 'regeneration', 20-40 years, 70-90 years, 120-140 years and 170-200 years.

The whole ground vegetation data set was submitted to Principal Components Analysis (PCA), after standardization of cover percentage values to mean $=0$ and variance $=1$, thereby equalling Euclidean distances between plant species to product-moment 
1 correlation coefficients. Plant species, coded as in Appendix 1, were projected on bi-plots of

2 factorial axes. Other bi-plots were used to show the projection of some additional variables on

3 the same factorial axes. Although somewhat neglected by plant ecologists after the rise of

4 methods derived from Correspondence Analysis (CoA), PCA with standardized variables was

5 chosen because of the ease with which it may reveal gradients as well as clusters in a complex

6 data matrix, without being influenced by rare species nor by preconceived hypotheses (Chae

7 and Warde, 2006; Bakkestuen et al., 2008). Comparisons done by Kenkel (2006) over a large

8 array of multivariate methods, including the commonly used Detrended Correspondence

9 Analysis (DCA) concluded to the superiority of PCA to decrease the number of dimensions of

10 large data sets. Ellenberg's indices and several measured environmental descriptors were

11 projected as additional (passive) variables in order to facilitate the ecological interpretation of

12 PCA axes.

In each studied forest and in each beech habitat (Endymio-Fagetum and Ilici-Fagetum)

the between-sample floristic variation was measured by summing up variance components of sample scores along the first three PCA components. This was used as a measure of $\beta$ diversity according to Ter Braak (1983).

In order to verify whether gradients and clusters revealed by indirect gradient analysis (PCA) could be defined on the basis of environmental parameters measured at each sampling

21 plot a Redundancy Analysis (RDA) was performed, using two matrices, (i) ground vegetation data used for PCA, (ii) environmental data listed in Appendix 2. Note that Ellenberg's indices were not used in this analysis, given that they give only an indirect view of the environment. Thereafter a partial Redundancy Analysis (partial RDA) was performed, in order to verify that the composition of ground vegetation could be explained by stand and ground properties 
1 when the confounding influence of geographical distance was discarded. For that purpose the

2 five forests were added as five qualitative variables which were coded as 1 or 0 according to 3 sample location.

4

Given that spatial autocorrelation was expected due to our nested sampling design, we used Signed Mantel tests (Oberrath and Böhning-Gaese, 2001) to investigate several plantenvironment relationships within each of the studied forests.

All calculations were done under Microsoft ${ }^{\circledR}$ EXCEL $\AA$ using the Addinsoft ${ }^{\circledR}$ XLSTAT® statistical software.

\section{Results}

\section{Principal Components Analysis: the F1-F2 bi-plot}

The vegetation data matrix which was analysed by PCA was comprised of 995 rows (sample plots) and 141 columns (species). The first three components of PCA (those which were interpretable in terms of ecological factors as a rule of thumb) extracted $11 \%$ of the total variance, a weak although significant percentage (Kaiser criterium for eigen values and Bartlett's test of sphericity) which is explained by the high number of variables (141) included in the analysis and the ground noise caused by scarcely represented plant species. The projection of plant species in the plane of the first two components of PCA (eigen values 7.61 and 4.55 , respectively) showed three directions over which the cloud of species was stretched (here called 'branches'), which were noted A, B and C (Fig. 1). The A branch was stretched along the positive side of factor F1. Species projected far from the origin along the 
1 A branch were considered characteristic of this branch and were noted as A group (Table 2).

2 All these species were positively correlated with F1. No branch was visible on the negative

3 side of this factor. Branches B and C were stretched on opposite sides of F2, not far from the

4 origin along F1. Two groups of characteristic species, which were positively and negatively

5 correlated with F2, respectively, were noted as B and C groups (Table 2). Fagus sylvatica

6 (Fga) and Rubus fruticosus agg. (Rfr) were projected in an intermediate position between A

7 and B branches, both species being correlated positively with F1.

8

9

The calculation of variable scores (Table 3) and the projection (Fig. 1) of additional variables in the F1-F2 species plane showed that F1 was positively correlated with Fertility, pH and Wetness Ellenberg's indices, while it was negatively correlated with Ellenberg's Light index and Humus Index. Among canopy and sub-canopy descriptors, F1 was positively correlated with canopy and sub-canopy hornbeam cover and total canopy cover. Factor F1 was positively correlated with vascular and total species richness and negatively with moss richness. Gross disturbance categories (undisturbed, weak disturbance, severe disturbance) of the ground floor were poorly correlated with F1.

Factor F2 was positively correlated with Humus Index and with Ellenberg's Light index (Table 3, Fig. 1), while it was negatively correlated with $\mathrm{pH}$ and Fertility Ellenberg's indices. Among canopy and sub-canopy descriptors, F1 was positively correlated with canopy beech cover and total canopy cover. Factor F1 was negatively correlated with vascular and total species richness. Gross disturbance categories were poorly correlated with F1.

The projection of samples in the F1-F2 bi-plot showed that A, B and C species groups were not equally distributed in the five studied forests and in the two studied beech habitats 
1 (Fig. 2, compare with Fig. 1). The B group (positive values of F2) was mostly represented in

2 the Ilici-Fagetum (IF) and its characteristic species were better displayed in Brotonne. The A

3 and $\mathrm{C}$ groups (positive values of $\mathrm{F} 1$ and negative values of $\mathrm{F} 2$, respectively) were mostly

4 represented in the Endymio-Fagetum (EF) and their characteristic species were better

5 displayed in Retz and Compiègne, respectively. Lyons EF was intermediate between A and C

6 species branches. It should be noted that EF and IF formed a continuum, without any clear-cut

7 limit between them, and that Brotonne EF was projected at the same position (i.e. exhibited 8 the same correlation with F1 and F2) than Eawy IF and Retz IF.

9

\section{Principal Components Analysis: the F2-F3 bi-plot}

While B and C branches were projected on opposite sides of F2, as mentioned above, an additional branch $\mathrm{D}$ was displayed on the negative side of $\mathrm{F} 3$, while $\mathrm{B}$ and $\mathrm{C}$ were both projected on its positive side (Fig. 3). The characteristic group of species corresponding to the D branch (D group) shared two species with the A group: Lamium galeobdolon agg. (Lga) and Athyrium filix-femina (Afi) (Table 2).

Contrary to F1 and F2, factor F3 (eigen value 3.42) was associated with ground disturbance cover variables, being positively correlated with weak and severe disturbance cover and negatively correlated with undisturbed cover (Table 3, Fig. 3). Factor F3 was negatively correlated with moss species richness and subcanopy cover.

The projection of samples on the F2-F3 bi-plot (Fig. 4, compare with Fig. 3) showed that the D group (negative values of F3) was mostly represented in Lyons EF and Eawy EF. Other factors were not considered, because they did not exhibit any new species group, but 
1 rather subdivided and reassembled A, B, C and D branches, without any clear-cut association

2 with environmental variables. We considered them as belonging to ground noise.

4 Floristic heterogeneity

Table 4 showed that floristic heterogeneity, as ascertained from the variance of sample scores along the first three components of PCA, varied to a great extent according to forests and according to EF and IF beech habitats. More between-sample variation was depicted by the Endymio-Fagetum compared to the Ilici-Fagetum in Compiègne, Retz and Lyons. Eawy remained at a very low level of floristic heterogeneity, whatever beech habitats and despite a

11 higher sampling effort (Table 1). In Brotonne the Ilici-Fagetum exhibited a higher floristic heterogeneity than the Endymio-Fagetum.

\section{Redundancy Analysis}

Permutation tests (Monte-Carlo simulation) showed that the vegetation data matrix and the environmental data matrix were not independent (Pseudo-F $=0.31, \mathrm{P}<0.0001$ ) despite of the fact that constrained variation (explained by environmental variables) was only $13 \%$ of total variation. The first three canonical axes extracted $46 \%$ of the constrained variation $(22 \%, 14 \%, 10 \%$, respectively). Indirect and direct gradient analyses gave similar results. A comparison between corresponding species bi-plots of RDA (Fig. 5) and PCA (Figs. 1, 3) showed that the same four species groups were depicted by both analyses. Correlation coefficients between RDA scores and PCA coordinates of plant species along the first three axes were highly significant $(r=0.94,0.93,0.72$, respectively, all with $\mathrm{P}<0.0001)$. 
A much simpler pattern was exhibited when the effect of geographical distance (and

2 associated factors such as climate and past history) was eliminated (partial RDA). The two

3 habitats EF and IF were clearly separated along Axis 1 (17.6\% of constrained variation),

4 Endymio-Fagetum samples being projected on its positive side while Ilici-Fagetum samples

5 were projected on its negative side (Fig. 6). Among forest vegetation plant species, Milium

6 effusum (Mef), Athyrium filix-femina (Afi), Lamium galeobdolon agg. (Lga), Kindbergia

7 praelonga (Kpr), Hyacinthoides non-scriptus (Hno) and Carpinus betulus (Cpe) were

8 projected far from the origin on the positive side of Axis 1, while Ilex aquifolium (Iaq),

9 Pteridium aquilinum (Paq), Deschampsia flexuosa (Dfl), Molinia caerulea (Mca), Carex

10 pilulifera (Cpi) and Polytrichastrum formosum (Pfo) were projected far from the origin on its

11 negative side (Fig. 6). Mantel tests on the set of plant species showed that Ellenberg's indices

12 for $\mathrm{pH}$ and Fertility were positively correlated with Axis $1\left(\mathrm{r}_{\mathrm{M}}=0.41, \mathrm{P}<0.001\right.$ and $\mathrm{r}_{\mathrm{M}}=$

$130.31, \mathrm{P}<0.001$, respectively), and Light Index was negatively correlated with the same axis

$14\left(r_{M}=-0.31, P<0.001\right)$. The Wetness index exhibited a weak (although significant) negative

15 correlation with Axis $1\left(r_{M}=-0.02, P<0.01\right)$.

16

The projection of environmental variables (listed in Appendix 2) showed that Axis 1 of partial RDA was positively correlated with hornbeam canopy cover $(\operatorname{Cov} 1, r=0.36)$ and hornbeam subcanopy cover (Cov5, $\mathrm{r}=0.23)$, and was negatively correlated with Humus Index (H.I., $\mathrm{r}=-0.42)$ and holly (Ilex aquifolium) shrub cover $(\operatorname{Cov} 14, \mathrm{r}=-0.31)$.

The architecture of the cloud of samples in the plane of the first two axes of partial RDA (Fig. 6) showed a parabolic arrangement which is reminiscent of a Guttman effect (also 
1 information is provided by the first canonical axis (Hill and Gauch, 1980). As a consequence

2 further canonical axes were not taken into account: they were considered as ground noise.

3

\section{The indicator value of the Humus Index at regional and local level}

Among other environmental variables measured in our study sites, the Humus Index was given a prominent position by partial RDA: its strong negative score along the main gradient (Axis 1) and the subordinate gradient (Axis 2) depicted by this analysis indicated that it explained a large part of variation in the composition of beech forest plant habitats. We tested the relationships between the Humus Index and several community indices calculated at the sample level: species richness of vascular plants and mosses, average Ellenberg's indices and percent cover by species belonging to the four groups depicted by PCA. In order to avoid the confounding influence of discrepancies between forests (as exemplified by PCA bi-plots) Mantel statistics were calculated in each forest, separately (Table 5). In all five forests the Humus Index was positively correlated with moss richness and negatively correlated with vascular richness. In Eawy the correlation was weak, although still significant. In all forests, the Humus Index was negatively correlated with $\mathrm{pH}$ and Fertility Ellenberg's indices. The correlation between the Humus Index and the Light Ellenberg's index was positive in four out of five forests, Eawy being the exception with a weak (although significant) negative value. The correlation between the Humus Index and the Wetness Ellenberg's index was negative in four out of five forests, Retz being the exception with a weak (although significant) positive value).

The four groups of species depicted by PCA exhibited homogeneous trends whatever the forest considered. The surface covered by species belonging to A, C and D groups was 
1 negatively correlated with the Humus Index, while the correlation was positive for the B group (Table 5).

Our study confirmed that the humus form, considered as a synthetic indicator of the soil nutrient regime (Wilson et al., 2001; Pyatt et al., 2001; Ponge et al., 2002), can explain a large part of the observed variation in the floristic composition of beech forests established on acid to neutral soils. Over a large set of beech stands, belonging to two common habitats, Endymio-Fagetum (EF) and Ilici-Fagetum (IF), our study confirmed the opposite trends in

11 vascular and moss species richness which had been shown in Brotonne and Saint-Palais IF beech stands (Lalanne et al., 2008): at the sampling plot level, when the Humus Index increases, passing from mull (Humus Index 1-4) to moder (Humus Index 5-7) then to mor (Humus Index 8), moss species richness increases and vascular species richness decreases, thereby reinforcing the view of phylogenetic conservatism of the ecological niche (Prinzing et al., 2001). This observation is in agreement with Brunet et al. (1997) and Roem and Berendse (2000) who showed that at local level vascular plant species richness decreases when soil acidity increases in woodland and grassland, respectively. It should be highlighted, however, that this observation holds for plot scale only and does not preclude the existence of an opposite trend at larger scales (Levin, 2000; Gering and Crist, 2002; Rajaniemi et al., 2006).

21 Given a regional species pool (Zobel, 1997) more fertile, less acidic soils, will allow more vascular species to cohabit at small scale and share a dearth of nutrients through common mycelial networks and facilitation mechanisms (Bruno et al., 2002; Hart et al., 2003). 
In all studied forests; the Humus Index was positively correlated with $\mathrm{pH}$ and Fertility

2 Ellenberg's indices, reinforcing the view expressed by Ulrich (1994) and Ponge (2003) that humus forms, nutrient levels and soil acidity are strongly interconnected and interact with

4 vegetation types according to a limited number of ecosystem strategies (Odum, 1969) or assembly rules (Belya and Lancaster, 1999). In a comprehensive study of understory

6 vegetation comparing 99 even-aged oak forests located in northern France, Bergès et al.

7 (2006) showed that humus forms, Ellenberg's Reaction and Nitrogen indices (here called $\mathrm{pH}$ and Fertility), $\mathrm{H}^{+}, \mathrm{Ca}$ and $\mathrm{P}$ concentrations explained the main part of the observed floristic variation. Similar results were obtained by Wilson et al. (2001) in 70 sites covering the range of soil nutrient conditions prevailing in plantation forests of the United Kingdom. In both 11 cases nitrogen acted as a pollutant rather than as a nutrient and was not associated with this soil fertility gradient. This further justifies that the 'Nitrogen index' of Ellenberg (1974) was renamed 'Fertility Index' by Hill et al. (1999).

In all but one studied forests the Humus Index was positively and negatively correlated with Light and Wetness Ellenberg's indices, respectively. In terms of causality this seems to indicate that moisture disfavours and light favours the accumulation of organic matter. That optimum (but not excess) moisture availability favours the circulation of nutrients is a matter of fact (Austin et al., 2004) and the exception of the Retz forest, which does not follow this general trend, can be explained by the high frequency of waterlogging, 21 which is currently associated with organic matter accumulation (Låg, 1971; Tate et al., 1995). 22 The observed (and at first sight surprising) correlation between light and organic matter accumulation can be explained if we take into account that beech stands on more acidic soils are less productive (Ponge et al., 1997), have less hornbeam and more oak, bracken and heather in the understory (Lawesson, 2000), thereby shed more light on the ground. If this 
1 hypothesis is true, it can be said that soil conditions (including humus form, acidity and

2 nutrient level) influence light conditions (Endler, 1993) by decreasing the influence of shade-

3 casting easy-to-decay species such as hornbeam and favouring light-demanding hard-to-decay

4 species such as oak, bracken, bilberry and heather, thereby reinforcing contrasts between

5 vegetation types (Miles, 1985). Rather than simple causal effects, our results point to the

6 existence of a global factor encompassing a large array of microclimate and soil conditions,

$7 \quad$ which will be discussed further below.

Among the four groups of forest vegetation species depicted by PCA in beech forests of north-western France, the B group was the only one to be positively correlated with the Humus Index, thus to be favoured by more acidic soils with a high Humus Index (mor and moder). Species of this group (Carex pilulifera, Deschampsia flexuosa, Holcus mollis, Ilex aquifolium, Lonicera periclymenum, Polytrichastrum formosum, Pteridium aquilinum,

Thuidium tamariscinum) are known for a long time for their preference for acid soils in a wide array of oak and beech European forests (Olsen, 1925; Le Tacon and Timbal, 1973; Ellenberg, 1974) and H-concentration was shown to be the driving factor (Falkengren-Grerup and Tyler, 1993), although many other related processes may be involved, too (Lee 1999). Among the sub-associations and variants of the Ilici-Fagetum described by Bardat (1993) in the same region, this group is better represented by the Ilici-Fagetum holcetosum, which is typically observed in forests on alluvial terraces of the Seine valley (Brotonne, Eawy, Lyons).

21 This is congruent with our results (Figs. 1,2) except that this group was also present in Retz 22 IF and at least partially in Compiègne IF, two forests which were not covered by the study cited above. Despite the vascular vs moss trend mentioned above, acidotolerant species of the B group are not phylogenetically and physiognomically related (a shrub, a liana, two grasses, a sedge-grass, a fern and two mosses). Within the limits of present knowledge, they rather 
1 have in common to be perennial, to exhibit strong interference competition and anti-herbivore

2 defence (Jarvis, 1964; Coley et al., 1985; Dolling et al., 1994) and to excrete a variety of

3 organic acids with chelating properties in reaction to Al-toxicity (Schöttelndreier et al., 2001).

4 These characters stem in patch occupancy (Ovington, 1953; Watt, 1976), thereby decreasing

5 species coexistence at the plot level while allowing it over wide areas.

6

Beside these results, the case of Brotonne should be highlighted. Figure 2 showed that most samples taken in the Endymio-Fagetum had positive values for F2, thus exhibited a floristic composition which did not resemble that of the same habitat in other forests of the same region. The shift of Brotonne EF towards an acidotolerant species distribution (B branch) can be explained by the particular abundance of Deschampsia flexuosa, known to thrive in the presence of atmospheric deposition of varied origin (Scale, 1980; FalkengrenGrerup, 1986; Britton et al., 2003), in this air-polluted forest downwind of Le Havre (Solmon et al., 2004; Croisé et al., 2005). The better representation of acidotolerant vegetation in Brotonne was also reflected in a higher level of floristic variation ( $\beta$-diversity) of the IliciFagetum (Table 4).

All other species groups exhibited by PCA (A, C, D) were negatively correlated with the Humus Index, thus they were favoured by mull and less acidic soil conditions. However, they diverged in their species composition, according to other environmental or geographical factors which act as filters selecting subsets of species within regional pools (Weiher and Keddy, 1995).

The A group (Table 2) included a liana (Hedera helix), three grasses (Melica uniflora, Milium effusum, Poa nemoralis), three sedge-grasses (Carex pendula, C. remota, C. 
1 sylvatica), ten forbs, among which two were annual (Geranium robertianum, Moehringia

2 trinervia) and eight were perennial (Circaea lutetiana, Euphorbia amygdaloides, Galium

3 odoratum, Geum urbanum, Lamium galeobdolon agg., Oxalis acetosella, Veronica montana,

4 Viola reichenbachiana) and two ferns (Athyrium filix-femina, Dryopteris filix-mas). All these

5 plants are commonly associated with nutrient-rich and moderately moist environments

6 (Rameau et al. 1989). This group is better represented by the Endymio-Fagetum typicum,

7 typically observed on loess deposits north of the river Seine (Bardat 1993). PCA showed that

8 it was mostly present in Retz EF (Fig. 2), which exhibited a high level of $\beta$-diversity (Table $94)$.

The $\mathrm{C}$ group included three trees (Acer campestre, A. platanoides, Tilia platyphyllos),

The increase in the part played by annual herbs $(0 \rightarrow 2 \rightarrow 4)$ along the $B \rightarrow A \rightarrow C$ gradient is worthy to notice: it indicates an increasing nutrient availability, allowing the rapid 
1 growth and reproduction of plants which are unable to store nutrients in perennial organs

2 (Fédoroff et al., 2005).

3 vehicles, have been undisturbed for the last 50 years.

The D group, which was mostly present in Lyons EF and Eawy EF (Figures, 3, 4), was comprised of two species which already belonged to the A group: the fern A. filix-femina and the perennial forb L. galeobdolon. Other species were the trees Acer pseusoplatanus and Carpinus betulus, the shrubs Rubus idaeus, Ruscus aculeatus and Taxus baccata, the sedgegrass Carex ovalis, the perennial forbs Anemone nemorosa, Callitriche sp., Digitalis purpurea, Hyacinthoides non-scripta, Lotus pedunculatus, Polygonatum multiflorum, Stellaria graminea, Stellaria nemorum and Viola riviniana, the annual forb Galeopsis tetrahit agg., and the mosses Atrichum undulatum, Brachythecium rutabulum, Hypnum cupressiforme agg., Isothecium myosuroides, Kindbergia praelonga and Plagiothecium denticulatum. Most remarkable features are the diversity of mosses (see the projection of the moss richness vector on Figure 3) and of spring-flowering geophytes. Several species (C. ovalis, Callitriche sp., L. pedunculatus, Stellaria nemorum) are known for their affinity to wet environments. The D group was better represented by the Endymio-Fagetum aretosum (Bardat, 1993), which is the most hygrophilic sub-association of the Endymio-Fagetum, established in bottom woodland within the study region. The D group of species was projected on the negative side of Factor F3 (Fig. 3), which was positively correlated with weak disturbance and negatively correlated with undisturbed ground cover, thereby indicating that corresponding plots were poorly rutted by exploitation traffic. In the absence of straightforward data on management practices it may be thought that wetter environments, given the difficulty of timber extraction with modern 4 
All species groups depicted by PCA were confirmed by RDA, on the basis of stand

2 properties (age, basal area, stem density, composition of canopy, subcanopy and shrub layers)

3 and ground disturbance (traffic cues, wood deposits). This seems to indicate that in the

4 context of the studied region ground vegetation responded to local factors which could be

5 described fairly well by a visual inspection of ground and above strata. As a corollary, this

6 points to the existence of a common regional species pool without any additional filter than

7 described by plot-scale local environment.

8

9

Once local environmental particularities have been ruled out by partialling out the geographical position of sampling plots, a simpler pattern arose, with a single gradient of soil fertility/acidity/light which was exemplified by Axis 1 of partial RDA (Fig. 6). The distribution of species showed a gradient from acidophily to acido-intolerance which corresponded to a continuum from the Ilici-Fagetum (species of the B group) to the EndymioFagetum (species of A, C and D groups). The two dominant species of these habitats, respectively I. aquifolium (Iaq) and H. non-scripta (Hno), were projected far from the origin, on negative and positive sides of Axis 1, respectively. This gradient of decreasing acidity and light and increasing fertility and Humus Index was associated with an increase in hornbeam cover, both in canopy (Cov 1) and subcanopy ( $\operatorname{Cov} 5)$. Whether hornbeam is a cause of decreasing light for forest-floor vegetation is out of doubt, given its dense canopies strongly select shade-tolerant species (Kwiatkowska et al., 1997). Whether hornbeam is a cause or a consequence of variation in soil fertility/acidity and humus form does not deserve any straightforward answer, although feed-back relationships can be suspected (Ponge, 2003). Most studies comparing forest stands with and without hornbeam did not take into account historical or environmental reasons why hornbeam was present or absent and they ascribed to sylviculture only the observed effects (Aubert, et al. 2004; Decocq et al., 2005). Similar flaws 
1 can be found in comparisons between coppice woods of varying nature and adjoining full-

2 grown forest stands (Hölscher et al., 2001). This lack of account for the spontaneous

3 establishment of $C$. betulus in natural or managed forests (Kwiatkowska et al., 1997;

4 Lawesson, 2000) is not so important for explaining variations in corticolous assemblages

5 (Bardat and Aubert, 2007) but it may flaw any conclusion about the impact of hornbeam on

6 forest-floor plant assemblages when mature forests of unknown past history are compared. As

7 shown by Decocq (2000) working on 157 sample plots distributed over the widest possible

8 range of geological substrates prevailing in northern France mixed-hardwood forests, forest-

9 floor vegetation was more influenced by the geological substrate than by the composition of

10 the overstory. However, when care is taken for substrate conditions being identical, the

11 positive impact of hornbeam on the soil fertility of beech forests, which is mainly due to

12 better litter quality of hornbeam compared to beech (Lemée and Bichaut, 1973), and 13 consequent influences on forest-floor vegetation, can be assessed less ambiguously (Decocq 14 et al., 2004; Ponge and Chevalier, 2006; Van Calster et al., 2007). Awaiting further 15 clarification of the 'hornbeam' effect, it can be hypothesized that the combined influence of 16 geological substrate, natural establishment of hornbeam and sylviculture (in particular 17 coppicing) results in a feed-back loop in favour of mull humus forms and associated 18 vegetation.

The variation of ground vegetation can thus be explained by a combination of humus 21 quality, soil fertility, soil acidity and light along a single environmental gradient from poorly 22 productive (and species-poor) to highly productive (and species-rich) forest ecosystems, in accordance with some (but far from all) theoretical studies (Ulrich, 1994; Bruno et al., 2002) and in line with experimental and descriptive studies (Falkengren-Grerup and Tyler, 1993; 
1 multiple but strongly interconnected factors stemming in a limited number of stable states

2 (Perry, 1995; Ponge, 2003; Beisner et al., 2003), are superimposed local effects of a more 3 complex (i.e. harder to discern) nature. Climate (Bakkestuen et al., 2008), atmospheric 4 deposition (Brandt and Rhoades, 1972; Falkengren-Grerup, 1986), past history (Peterken and 5 Game, 1984; Koerner et al., 1997; Gachet et al., 2007), management practices (Thomas et al., 6 1999; Decocq, 2000; Godefroid and Koedam, 2004), dispersal from sources of migration 7 (Björkman and Bradshaw, 1996; Bossuyt et al., 1999) and succession (Watt, 1934; Myster and Pickett, 1992; Godefroid et al., 2005) are supposed to act more or less independently in different forests (McCune and Allen, 1985), thereby creating the variegated forest habitats which could be described (but not necessarily fully explained) locally (Rol, 1937; Ricklefs, 11 1987; Huston, 1999).

\section{Acknowledgements}

The study was financially supported by a grant given to the junior author by the Office National des Forêts (ONF). Authors are grateful to local authorities for access to the sites and commodities and to Thierry Gautrot his help during field work. Luc Croisé (ONF) and Élisabeth Duguin (Météo-France) are acknowledged for providing data about atmospheric deposition and climate, respectively.

\section{References}

Aubert, M., Bureau, F., Alard, D., Bardat, J., 2004. Effect of tree mixture on the humic epipedon and vegetation diversity in managed beech forests (Normandy, France). Can. J. For. Res. 34, 233-248. 
2 Aubin, I., Gachet, S., Messier, C., Bouchard, A., 2007. How resilient are northern hardwood forests to human disturbance? An evaluation using a plant functional group approach. Écoscience 14, 259-271.

Austin, A.T., Yahdjian, L., Stark, J.M., Belnap, J., Porporato, A., Norton, A., Ravetta, D.A., Schaeffer, S.M., 2004. Water pulses and biogeochemical cycles in arid and semiarid ecosystems. Oecologia 141, 221-235.

9

Bakkestuen, V., Erikstad, L., Halvorsen, R., 2008. Step-less models for regional environmental variation in Norway. J. Biogeogr. 35, 1906-1922.

Bardat, J., 1993. Phytosociologie et écologie des forêts de Haute-Normandie. Leur place dans le contexte sylvatique ouest-européen. Bull. Soc. Bot. Centre-Ouest NS 11, 1-376.

Bardat, J., Aubert, M., 2007. Impact of forest management on the diversity of corticolous bryophyte assemblages in temperate forests. Biol. Conserv. 139, 47-66.

Bartoli, M., Tran-Ha, M., Largier, G., Dumé, G., Larrieu, L., 2000. ECOFLORE, un logiciel simple de diagnostic écologique. Rev. For. Fr. 52, 530-546.

Beisner, B.E., Haydon, D.T., Cuddington, K., 2003. Alternative stable states in ecology. Front. Ecol. Environ. 1, 376-382. 
1 Belya, L.R., Lancaster, J., 1999. Assembly rules within a contingent ecology. Oikos 86, 402416.

Bergès, L., Gégout, J.C., Franc, A., 2006 Can understory vegetation accurately predict site index? A comparative study using floristic and abiotic indices in sessile oak (Quercus petraea Liebl.) stands in northern France. Ann. For. Sci. 63, 31-42.

Björkman, L., Bradshaw, R., 1996. The immigration of Fagus sylvatica L. and Picea abies (L.) Karst. into a natural forest stand in southern Sweden during the last 2000 years. J. Biogeogr. 23, 235-244.

Bossuyt, B., Hermy, M., Deckers, J., 1999. Migration of herbaceous plant species across ancient-recent forest ecotones in Central Belgium. J. Ecol. 87, 628-638.

Brandt, C.J., Rhoades, R.W., 1972. Effects of limestone dust accumulation on composition of a forest community. Environ. Pollut. 3, 217-225.

Britton, A., Marrs, R., Pakeman, R., Carey, P., 2003. The influence of soil-type, drought and nitrogen addition on interactions between Calluna vulgaris and Deschampsia flexuosa: implications for heathland regeneration. Plant. Ecol. 166, 93-105.

Brunet, J., Falkengren-Grerup, U., Tyler, G., 1997. Pattern and dynamics of the ground vegetation in south Swedish Carpinus betulus forests: importance of soil chemistry and management. Ecography 20, 513-520. 
1 Bruno, J.F., Stachowicz, J.J., Bertness, M.D., 2002. Inclusion of facilitation into ecological theory. TREE 18, 119-125.

3

4 Chae, S.S., Warde, W.D., 2006. Effect of using principal coordinates and principal components on retrieval of clusters. Comput. Stat. Data Anal. 50, 1407-1417.

6

Coley, P.D., Bryant, J.P., Chapin, S. FIII, 1985. Resource availability and plant antiherbivore defense. Science 230, 895-899.

9

Croisé, L., Ulrich, E., Duplat, P., Jaquet, O., 2005. Two independent methods for mapping bulk deposition in France. Atm. Environ. 39, 3923-3941.

Decocq, G., 2000. The 'masking effect' of silviculture on substrate-induced plant diversity in oak-hornbeam forests from northern France. Biodiv. Conserv. 9, 1467-1491. European temperate deciduous forest. Ann. For. Sci. 62, 313-323.

Decocq, G., Aubert, M., Dupont, F., Alard, D., Saguez, R., Wattez-Franger, A., de Foucault, B., Delelis-Dusollier, A., Bardat, J., 2004. Plant diversity in a managed temperate deciduous forest: understorey response to two silvicultural systems. J. Appl. Ecol. 41, 
1 Diekmann, M., 2003. Species indicator values as an important tool in applied plant ecology: a review. Basic Appl. Ecol. 4, 493-506.

3

4 Diekmann, M., Lawesson, J.E., 1999. Shifts in ecological behaviour of herbaceous forest species along a transect from northern Central to North Europe. Folia Geobot. 34, $127-$ 141.

Dolling, A., Zackrisson, O., Nilsson, M.C., 1994. Seasonal variation in phytotoxicity of bracken (Pteridium aquilinum L. Kuhn). J. Chem. Ecol. 20, 3163-3172.

Dufour, A., Gadallah, F., Wagner, H.H., Guisan, A., Buttler, A., 2006. Plant species richness and environmental heterogeneity in a mountain landscape: effects of variability and spatial configuration. Ecography 29, 573-584.

14

Dupouey, J.L., Dambrine, E., Laffite, J.D., Moares, C., 2002. Irreversible impact of past land use on forest soils and biodiversity. Ecology 83, 2978-2984.

Durin, L., Géhu, J.M., Noirfalise, A., Sougnez, N., 1967. Les hêtraies atlantiques et leur essaim bioclimatique dans le nord-ouest et l'ouest de la France. Bull. Soc. Bot. Nord

Ehrenfeld, J.G., Han, X., Parsons, W.F.J., Zhus, W., 1997. On the nature of environmental gradients: temporal and spatial variability of soils and vegetation in the New Jersey Pinelands. J. Ecol. 85, 785-798. 
1 Ellenberg, H., 1974. Zeigerwerte der Gefasspflanzen Mitteleuropas. Scripta Geobot. 9, 1-97.

2

EUR25, 2003. Interpretation manual of European Union habitats. European Commission, Brussels.

Falkengren-Grerup, U., 1986. Soil acidification and vegetation changes in deciduous forest in southern Sweden. Oecologia 70, 339-347.

Falkengren-Grerup, U., Tyler, G., 1993. Soil chemical properties excluding field-layer species from beech forest mor. Plant Soil 148, 185-191.

Fédoroff, E., Ponge, J.F., Dubs, F., Fernández-González, F., Lavelle, P., 2005. Small-scale response of plant species to land use intensification. Agr. Ecosyst. Environ. 105, 283290.

Gachet, S., Leduc, A., Bergeron, Y., Nguyen-Xuan, T., Tremblay, F., 2007. Understory vegetation of boreal tree plantations: differences in relation to previous land use and natural forests. For. Ecol. Manag. 242, 49-57.

Gering, J.C., Crist, T.O., 2002. The alpha-beta-regional relationship: providing new insights into local-regional patterns of species richness and scale dependence of diversity components. Ecol. Lett. 5, 433-444. 
1 Gillet, F., Murisier, B., Buttler, A., Gallandat, J.D., Gobat, J.M., 1999. Influence of tree cover

Godefroid, S., Koedam, N., 2004. Interspecific variation in soil compaction sensitivity among forest floor species. Biol. Conserv. 119, 207-217.

Godefroid, S., Massant, W., Koedam, N., 2005. Variation in the herb species response and the humus quality across a 200-year chronosequence of beech and oak plantations in Belgium. Ecography 28, 223-235.

Graae, B.J., Sunde, P.B., 2000. The impact of forest continuity and management on forest floor vegetation evaluated by species traits. Ecography 23, 720-731.

Härdtle, W., von Oheimb, G., Friedel, A., Meyer, H., Westphal, C., 2004. Relationship between $\mathrm{pH}$-values and nutrient availability in forest soils. The consequences for the use of ecograms in forest ecology. Flora 199, 134-142.

Hart, M.M., Reader, R.J., Klironomos, J.N., 2003. Plant coexistence mediated by arbuscular mycorrhizal fungi. TREE 18, 418-423.

Hermy, M., Honnay, O., Firbank, L., Grashof-Bokdam, C., Lawesson, J.E., 1999. An ecological comparison between ancient and other forest plant species of Europe, and the implications for forest conservation. Biol. Conserv. 91, 9-22. 
1 Hill, M.O., Bell, N., Bruggeman-Nennenga, M.A., Bruguès, M., Cano, M.J., Enroth, J., Flatberg, K.I., Frahm, J.P., Gallego, M.T., Garilleti, R., Guerra, J., Hedenäs, L., Holyoak, D.T., Hyvönen, J., Ignatov, M.S., Lara, F., Mazimpaka, V., Muñoz, J., Söderström, L., 2006. An annotated checklist of the mosses of Europe and Macaronesia. J. Bryol. 28, 198-267.

Hill, M.O., Gauch, H.G. Jr, 1980. Detrended correspondence analysis: an improved ordination technique. Vegetatio 42, 47-58.

Hill, M.O., Mountford, J.O., Roy, D.B., Bunce, R.G.H., 1999. Ellenberg's Indicator Values for British Plants. Natural Environment Council, Institute of Terrestrial Ecology, Centre for Ecology and Hydrology, Huntingdon.

Hillebrand, H., 2005. Regressions of local on regional diversity do not reflect the importance of local interactions or saturation of local diversity. Oikos 110, 195-198.

Hölscher, D., Schade, E., Leuschner, C., 2001. Effects of coppicing in temperate deciduous forests on ecosystem nutrient pools and soil fertility. Basic Appl. Ecol. 2, 155-164.

Honnay, O., Verheyen, K., Butaye, J., Jacquemyn, H., Bossuyt, B., Hermy, M., 2002. Possible effects of habitat fragmentation and climate change on the range of forest plant species. Ecol. Lett. 5, 525-530.

Huston, M.A., 1999. Local processes and regional patterns: appropriate scales for understanding variation in the diversity of plants and animals. Oikos 86, 393-401. 
2 Jarvis, P.G., 1964. Interference by Deschampsia flexuosa (L.) Trin. Oikos 15, 56-78.

3

4 Keddy, P.A., 1992. Assembly and response rules: two goals for predictive community 5 ecology. J. Veg. Sci. 3, 157-164.

6

7 Kenkel, N.C., 2006. On selecting an appropriate multivariate analysis. Can. J. Plant Sci. 86, 8 663-676.

9

Kerguelen, M., 1993. Index Synonymique de la Flore de France. Muséum National d'Histoire Naturelle, Paris.

12

Klanderud, K., Totland, Ø., 2007. The relative role of dispersal and local interactions for alpine plant community diversity under simulated climate warming. Oikos 116, 12791288.

16

Koerner, W., Dupouey, J.L., Dambrine, E., Benoît, M., 1997. Influence of past land use on the vegetation and soils of present day forest in the Vosges mountains, France. J. Ecol. 85, 351-358.

Kwiatkowska, A.J., Spalik, K., Michalak, E., Palínska, A., Panufnik, D., 1997. Influence of the size and density of Carpinus betulus on the spatial distribution and rate of deletion of forest-floor species in thermophilous oak forest. Plant Ecol. 129, 1-10. 
1 Låg, J., 1971. Some relationships between soil conditions and distribution of different forest vegetation. Acta Agr. Fenn. 123, 118-125.

3

4 Lalanne, A., 2006. Système sylvicole, exploitation forestière: impacts respectifs sur l'état de conservation d'habitats forestiers planitiaires atlantiques. Doctorate Thesis, Muséum National d'Histoire Naturelle, Paris.

Lalanne, A., Bardat, J., Lalanne-Amara, F., Gautrot, T., Ponge, J.F., 2008. Opposite responses of vascular plant and moss communities to changes in humus form, as expressed by the Humus Index. J. Veg. Sci., 19, 645-652.

Lawesson, J.E., 2000. Danish deciduous forest types. Plant Eco. 151, 199-221.

Lee, J.A., 1999. The calcicole-calcifuge problem revisited. Adv. Bot. Res. 29, 1-30.

Lemée, G., Bichaut, N., 1973. Recherches sur les écosystèmes des réserves biologiques de la forêt de Fontainebleau. II. Décomposition de la litière de feuilles des arbres et libération des bioéléments. Oecol. Plant. 8, 153-174.

Le Tacon, F., Timbal, J., 1973. Valeurs indicatrices des principales espèces végétales des hêtraies du Nord-Est de la France vis-à-vis des types d'humus. Rev. For. Fr. 25, 269-

Levin, S.A., 2000. Multiple scales and the maintenance of biodiversity. Ecosyst. 3, 498-506. 
1 McCune, B., Allen, T.F.H., 1985. Will similar forests develop on similar sites? Can. J. Bot.

Peterken, G.F., Game, M., 1984. Historical factors affecting the number and distribution of vascular plant species in the woodlands of Central Lincolnshire. J. Ecol. 72, 155-182. 
1 Ponge, J.F., 2003. Humus forms in terrestrial ecosystems: a framework to biodiversity. Soil Biol. Biochem. 35, 935-945.

3

4 Ponge, J.F., Arpin, P., Sondag, F., Delecour, F., 1997. Soil fauna and site assessment in beech stands of the Belgian Ardennes. Can. J. For. Res. 27, 2053-2064.

6

7 Ponge, J.F., Chevalier, R., 2006. Humus Index as an indicator of forest stand and soil properties. For. Ecol. Manag. 233, 165-175.

9

Ponge, J.F., Chevalier, R., Loussot, P., 2002. Humus Index: an integrated tool for the assessment of forest floor and topsoil properties. Soil Sci. Soc. Am. J. 66, 1996-2001.

Prinzing, A., Durka, W., Klotz, S., Brandl, R., 2001. The niche of higher plants: evidence for phylogenetic conservatism. Proc. Roy. Soc. London B 268, 2383-2389.

Pyatt, D.G., Ray, D., Fletcher, J., 2001. An ecological site classification for forestry in Great Britain. For. Comm. Bull. 124, 1-75.

Rajaniemi, T.K., Goldberg, D.E., Turkington, R., Dyer, A.R., 2006. Quantitative partitioning of regional and local processes shaping regional diversity patterns. Ecol. Lett. 9, 121-

Rameau, J.C., Mansion, D., Dumé, G., 1989. Flore Forestière Française. I. Plaines et Collines. Institut pour le Développement Forestier, Paris. 
1 Ricklefs, R.E., 1987. Community diversity: relative roles of local and regional processes. Science 235, 167-171.

3

4 Rodríguez-Loinaz, G., Onaindia, M., Amezaga, I., Mijangos, I., Garbisu, C., 2008. Relationship between vegetation diversity and soil functional diversity in native mixed-oak forests. Soil Biol. Biochem. 40, 49-60.

Roem, W.J., Berendse, F., 2000. Soil acidity and nutrient supply ratio as possible factors determining changes in plant species diversity in grassland and heathland communities. Biol. Conserv. 92, 151-161.

Rol, R., 1937. La flore de la forêt de Bercé (à propos d'un livre récent). Rev. Eaux Forêts 75, 493-500.

14

Scale, P.R., 1980. Changes in plant communities with distance from an $\mathrm{SO}_{2}$ source. In: Miller, P.R. (Ed.), Proceedings of the Symposium on Effects of Air Pollutants on Mediterranean and Temperate Forest Ecosystems, Riverside, California, June 1980. exudation by wild herbs in response to elevated Al concentrations. Ann. Bot. 87, 769775. 
1 Solmon, F., Sarrat, C., Serça, D., Tulet, P., Rousset, R., 2004. Isoprene and monoterpene biogenic emissions in France: modelling and impact during a regional pollution episode. Atm. Environ. 38, 3853-3865.

Tate, K.R., Parshotam, A., Ross, D.J., 1995. Soil carbon storage and turnover in temperate forests and grasslands: a New Zealand perspective. J. Biogeogr. 22, 695-700.

Ter Braak, C.J.F., 1983. Principal components biplots and alpha and beta diversity. Ecology $64,454-462$.

Thomas, S.C., Halpern, C.B., Falk, D.A., Liguori, D.A., Austin, K.A., 1999. Plant diversity in managed forests: understory responses to thinning and fertilization. Ecol. Applic. 9, 864-879.

Thompson, L., Thomas, C.D., Radley, J.M.A., Williamson, S., Lawton, J.H., 1993. The effect of earthworms and snails in a simple plant community. Oecologia 95, 171-178.

Ulrich, B., 1994. Process hierarchy in forest ecosystems: an integrative ecosystem theory. In: Hüttermann, A., Godbold, D. (Eds.), Effects of Acid Rain on Forest Processes. WileyLiss, New York, pp 353-397.

Van Calster, H., Baeten, L., De Schrijver, A., De Keersmaeker, L., Rogister, J.E., Verheyen, K., Hermy, M., 2007. Management driven changes (1967-2005) in soil acidity and the understorey plant community following conversion of a coppice-with-standards forest. For. Ecol. Manag. 241, 258-271. 
2 Van der Maarel, E., 1979. Transformation of cover-abundance values in phytosociology and its effects on community similarity. Vegetatio $39,97-114$.

4

Wamelink, G.W.W., Joosten, V., Van Dobben, H.F., Berendse, F., 2002. Validity of Ellenberg indicator values judged from physico-chemical field measurements. J. Veg. Sci. 13, 269-278.

Wamelink, G.W.W., Van Dobben, H.F., 2003. Uncertainty of critical loads based on the Ellenberg indicator value for acidity. Basic Appl. Ecol. 4, 515-523.

Watt, A.S., 1934. The vegetation of the Chiltern Hills, with special reference to the beechwoods and their seral relationships. J. Ecol. 22, 230-507.

Watt, A.S., 1976. The ecological status of bracken. Bot. J. Linn. Soc. 73, 217-239.

16

Weiher, E., Keddy, P.A., 1995. The assembly of experimental wetland plant-communities. Oikos 73, 323-335.

Wiens, J.A., 1984. On understanding a non-equilibrium world: myth and reality in community patterns and processes. In: Strong, D.R., Simberloff, D., Abele, L.G., Thistle, A.B. (Eds.), Ecological Communities: Conceptual Issues and the Evidence. Princeton University Press, Princeton, pp. 439-457. 
1 Wilson, S.McG., Pyatt, D.G., Malcolm, D.C., Connolly, T., 2001. The use of ground vegetation and humus type as indicators of soil nutrient regime for an ecological site classification of British forests. For. Ecol. Manag. 140, 101-116.

4

5 Zobel, M., 1997. The relative role of species pools in determining plant species richness: an 6 alternative explanation of species coexistence? TREE 12, 266-269.

7 


\section{$1 \quad$ Figure legends}

2

Figure 1. Principal Components Analysis. F1-F2 bi-plot of plant species and some additional variables. For the sake of clarity, arrows have not been indicated for plant species vectors. Species names coded as in Appendix 1 and Table 2

Figure 2. Principal Components Analysis. F1-F2 bi-plots of sampling plots in the five studied forests

Figure 3. Principal Components Analysis. F2-F3 bi-plot of plant species and some additional variables. For the sake of clarity, arrows have not been indicated for plant species vectors. Species names coded as in Appendix 1 and Table 2

Figure 4. Principal Components Analysis. F2-F3 bi-plots of sampling plots in the five studied forests

Figure 5. Redundancy Analysis. Axis 1-Axis 2 (top) and Axis 2-Axis 3 (bottom) bi-plots of plant species. For the sake of clarity, arrows have not been indicated for plant species vectors. Species names coded as in Appendix 1 and Table 2

Figure 6. Partial Redundancy Analysis. Axis 1-Axis 2 bi-plots of plant species (top left), sampling plots (top right) and environmental variables (bottom). For the sake of clarity, arrows have not been indicated for plant species and environmental vectors. Species names coded as in Appendix 1 and Table 2. Environmental variables coded as in Appendix 2 


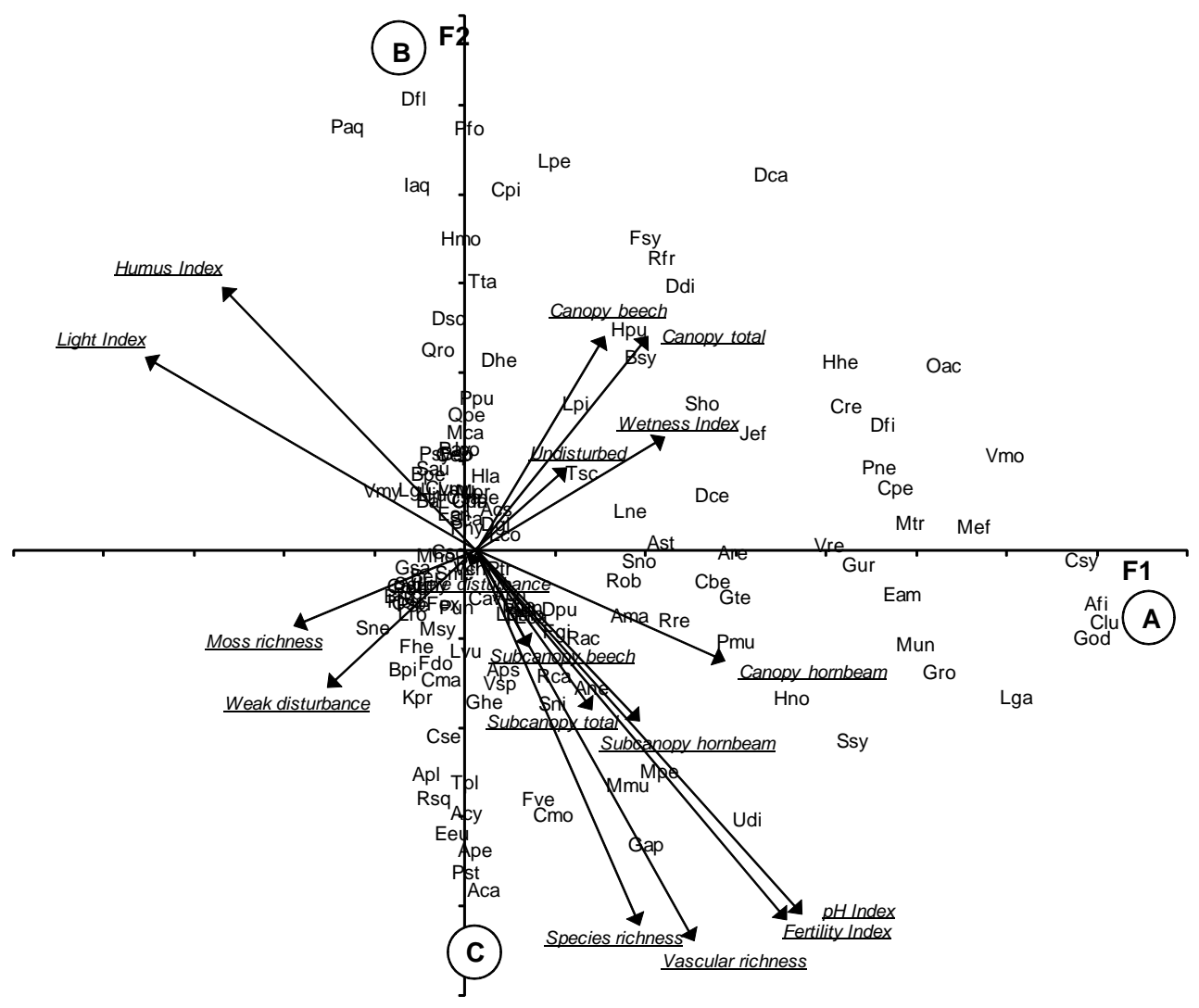

2 Fig. 1 

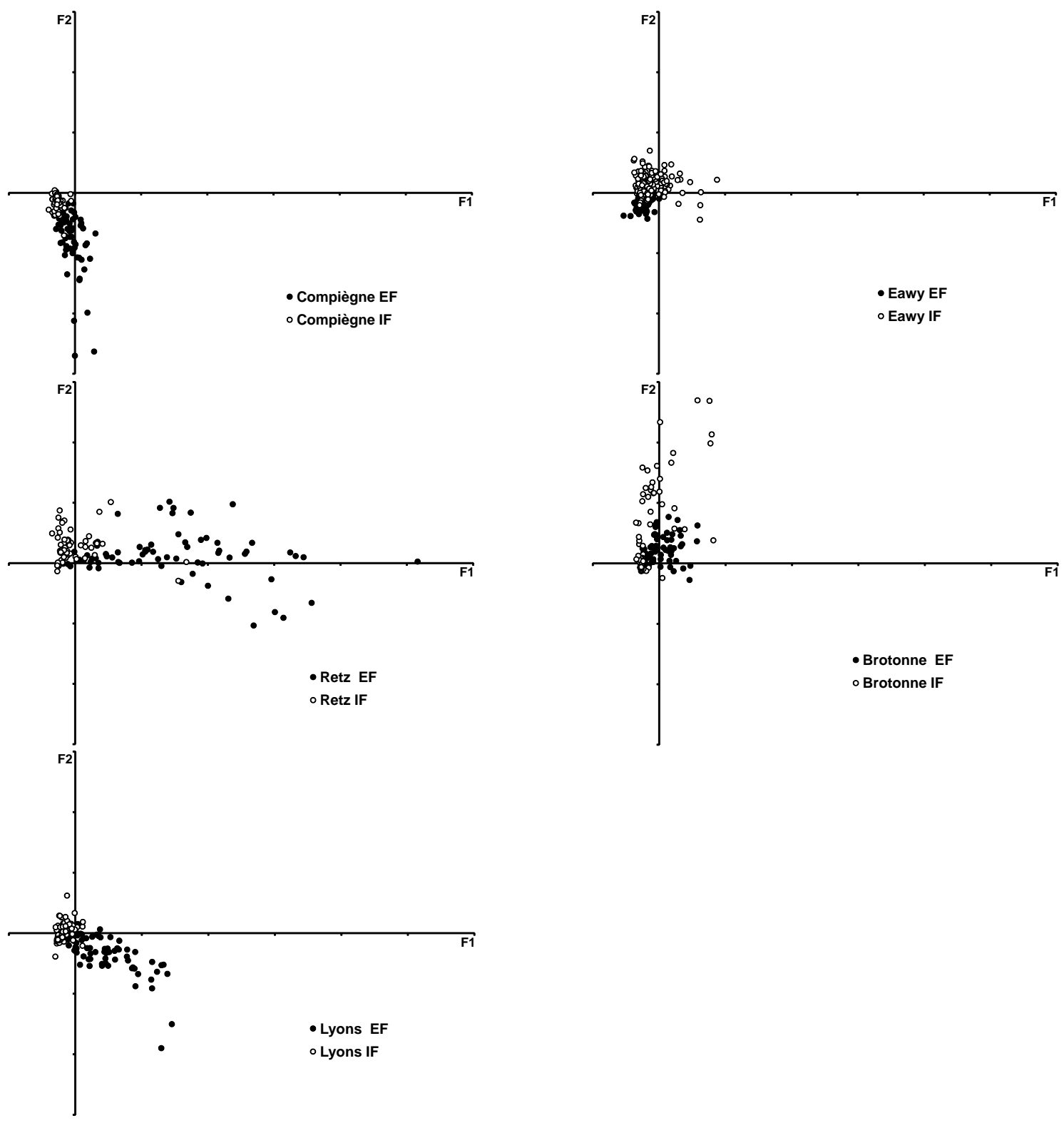

Fig. 2 


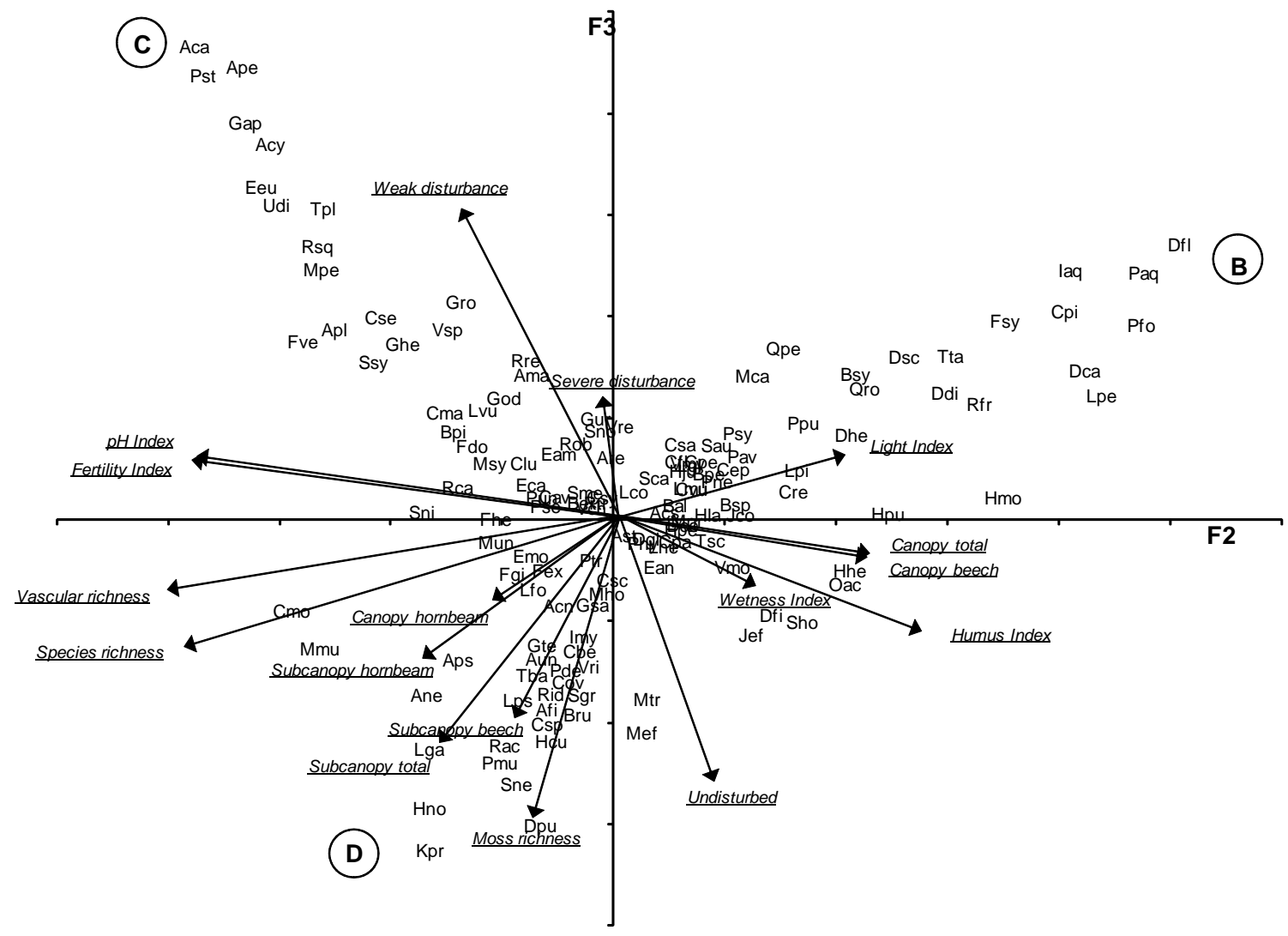

1

2 Fig. 3

3 

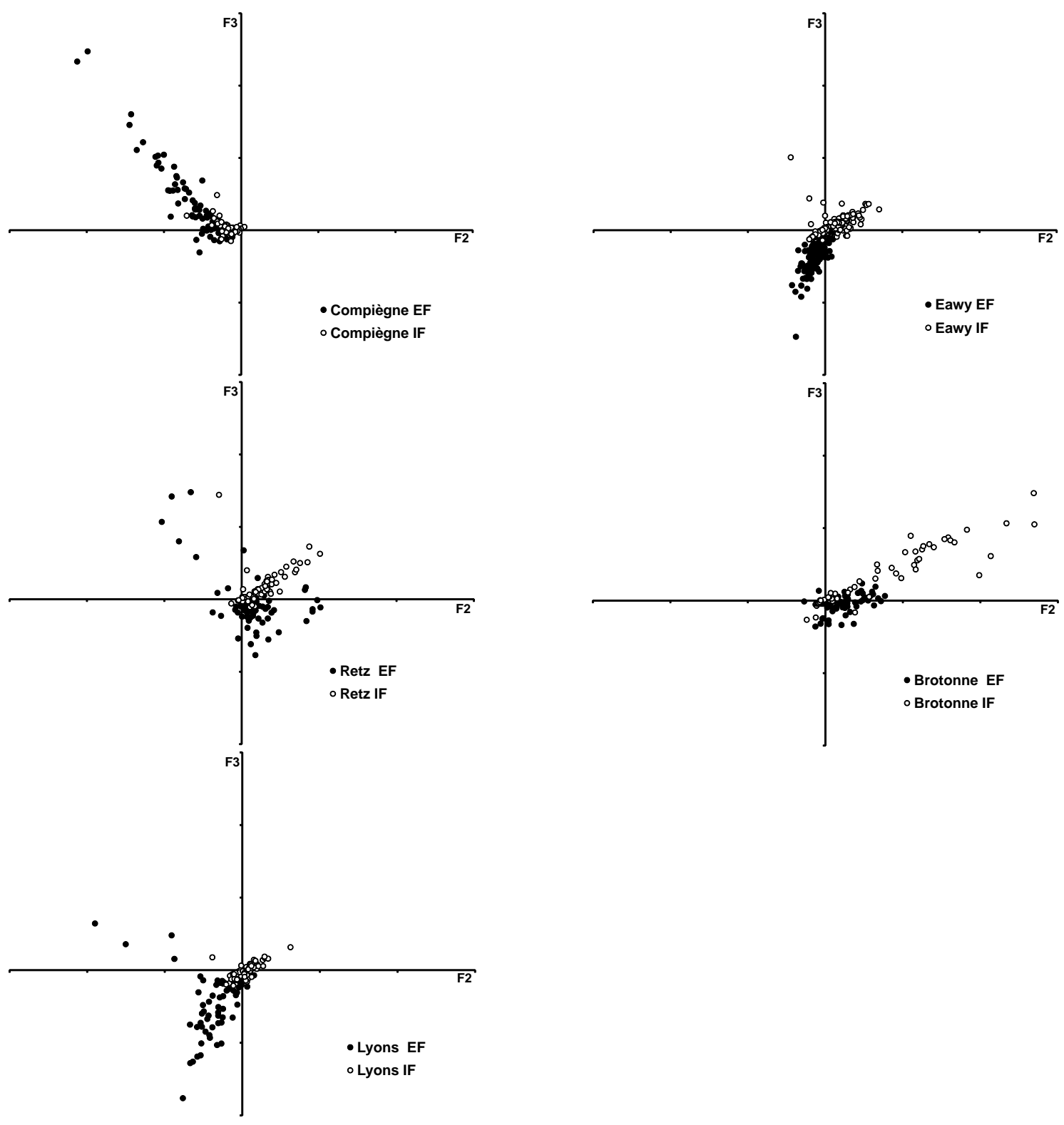

Fig. 4 

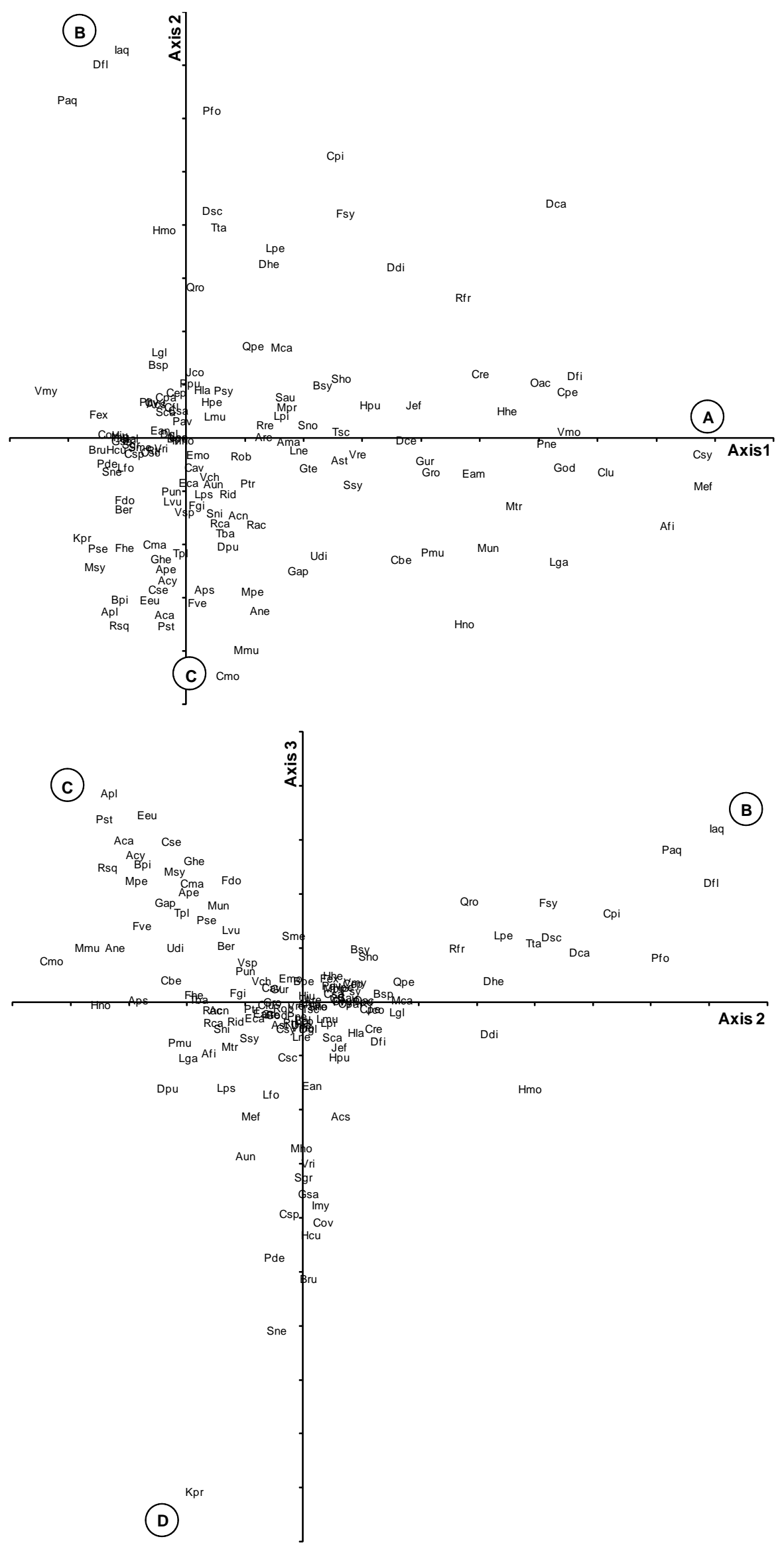

2 Fig. 5 

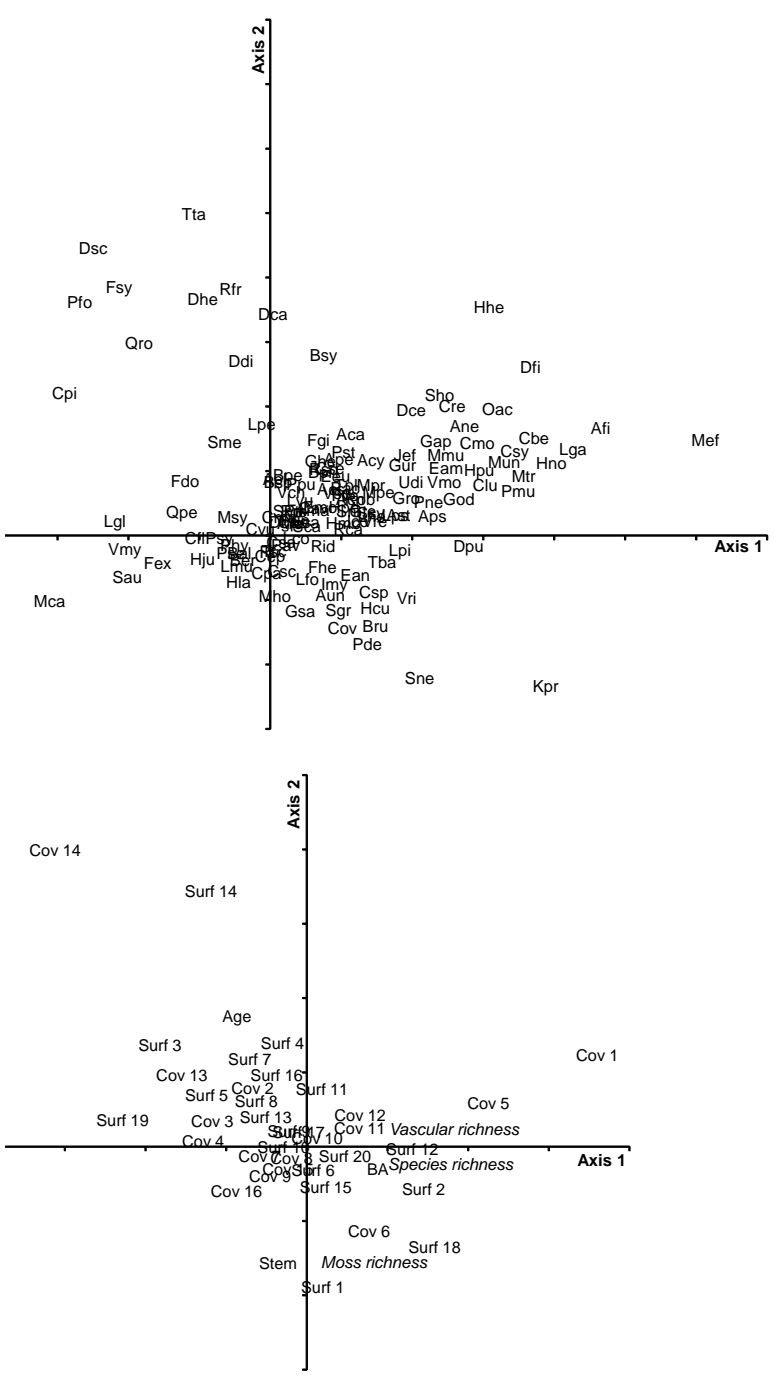

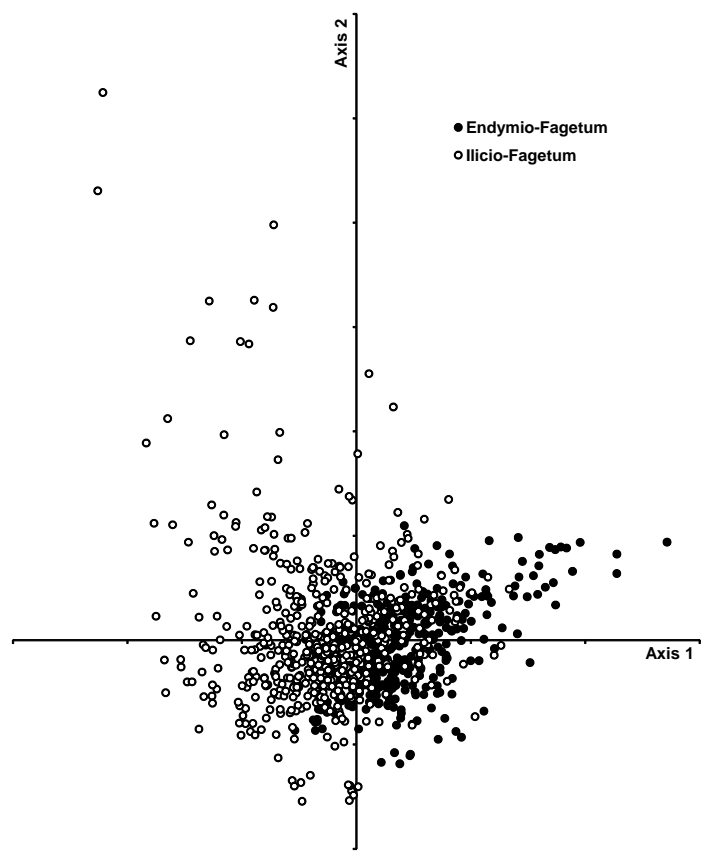

2 Fig. 6 
Table 1. Mean features of the five studied forests. Climate data averaged over 1978-2007. Atmospheric deposition data averaged over 1993-2004

\begin{tabular}{llllll}
\hline & Compiègne & Eawy & Retz & Brotonne & Lyons \\
\hline Number of sites & 33 & 74 & 25 & 34 & 33 \\
Number of plots & 165 & 370 & 125 & 170 & 165 \\
Latitude & $49^{\circ} 30^{\prime} \mathrm{N}$ & $49^{\circ} 35^{\prime} \mathrm{N}$ & $49^{\circ} 14^{\prime} \mathrm{N}$ & $49^{\circ} 36^{\prime} \mathrm{N}$ & $49^{\circ} 18^{\prime} \mathrm{N}$ \\
Longitude & $2^{\circ} 55^{\prime} \mathrm{E}$ & $1^{\circ} 21^{\prime} \mathrm{E}$ & $2^{\circ} 48^{\prime} \mathrm{E}$ & $0^{\circ} 44^{\prime} \mathrm{E}$ & $1^{\circ} 37^{\prime} \mathrm{E}$ \\
Surface & $14,400 \mathrm{ha}$ & $6,550 \mathrm{ha}$ & $13,000 \mathrm{ha}$ & $7,200 \mathrm{ha}$ & $10,700 \mathrm{ha}$ \\
Altitude & $32-148 \mathrm{~m}$ & $130-230 \mathrm{~m}$ & $155-241 \mathrm{~m}$ & $10-60 \mathrm{~m}$ & $67-178 \mathrm{~m}$ \\
Annual rainfall & $749 \mathrm{~mm}$ & $904 \mathrm{~mm}$ & $719 \mathrm{~mm}$ & $950 \mathrm{~mm}$ & $780 \mathrm{~mm}$ \\
Mean temperature & $10.9^{\circ} \mathrm{C}$ & $10.1^{\circ} \mathrm{C}$ & $10.7^{\circ} \mathrm{C}$ & $10.4^{\circ} \mathrm{C}$ & $10.9^{\circ} \mathrm{C}$ \\
Annual warming & $0.038^{\circ} \mathrm{C}$ & $0.077^{\circ} \mathrm{C}$ & $0.064^{\circ} \mathrm{C}$ & $0.070^{\circ} \mathrm{C}$ & $0.065^{\circ} \mathrm{C}$ \\
S deposition (kg.ha $\left.{ }^{-1} \cdot \mathrm{yr}^{-1}\right)$ & 4.6 & 6.9 & 4.6 & 6.8 & 5.9 \\
N deposition (kg.ha-1.yr-1) & 7.8 & 9 & 8.1 & 7.9 & 7.9 \\
\hline
\end{tabular}


Table 2. List of plant species placed in characteristic position by Principal Components Analysis, with their corresponding floristic groups

\begin{tabular}{|c|c|c|c|c|c|}
\hline Code & Species name & A group & B group & C group & D group \\
\hline Aca & Acer campestre & & & + & \\
\hline Apl & Acer platanoides & & & + & \\
\hline Aps & Acer pseudoplatanus & & & & + \\
\hline Acy & Aethusa cynapium & & & + & \\
\hline Ape & Alliaria petiolata & & & + & \\
\hline Ane & Anemona nemorosa & & & & + \\
\hline Afi & Athyrium filix-femina & + & & & + \\
\hline Aun & Atrichum undulatum & & & & + \\
\hline Bru & Brachythecium rutabulum & & & & + \\
\hline Csp & Callitriche sp. & & & & + \\
\hline Cov & Carex ovalis & & & & + \\
\hline Cpe & Carex pendula & + & & & \\
\hline Cre & Carex remota & + & & & \\
\hline Cpi & Carex pilulifera & & + & & \\
\hline Csy & Carex sylvatica & + & & & \\
\hline Cbe & Carpinus betulus & & & & + \\
\hline Clu & Circaea lutetiana & + & & & \\
\hline Cmo & Crataegus monogyna & & & + & \\
\hline Dfl & Deschampsia flexuosa & & + & & \\
\hline Dpu & Digitalis purpurea & & & & + \\
\hline Dfi & Dryopteris filix-mas & + & & & \\
\hline Eam & Euphorbia amygdaloides & + & & & \\
\hline Eeu & Evonymus europaeus & & & + & \\
\hline Fve & Fragaria vesca & & & + & \\
\hline Gte & Galeopsis tetrahit & & & & + \\
\hline Gap & Galium aparine & & & + & \\
\hline God & Galium odoratum & + & & & \\
\hline Gro & Geranium robertianum & + & & & \\
\hline Gur & Geum urbanum & + & & & \\
\hline Hhe & Hedera helix & + & & & \\
\hline Hmo & Holcus mollis & & + & & \\
\hline Hno & Hyacinthoides non-scripta & & & & + \\
\hline $\mathrm{Hcu}$ & Hypnum cupressiforme & & & & + \\
\hline laq & Ilex aquifolium & & + & & \\
\hline Imy & Isothecium myosuroides & & & & + \\
\hline $\mathrm{Kpr}$ & Kindbergia praelonga & & & & + \\
\hline Lga & Lamium galeobdolon & + & & & + \\
\hline Lpe & Lonicera periclymenum & & + & & \\
\hline Lps & Lotus pedunculatus & & & & + \\
\hline Mun & Melica uniflora & + & & & \\
\hline Mpe & Mercurialis perennis & & & + & \\
\hline Mef & Milium effusum & + & & & \\
\hline Mtr & Moehringia trinervia & + & & & \\
\hline $\mathrm{Mmu}$ & Mycelis muralis & & & + & \\
\hline Oac & Oxalis acetosella & + & & & \\
\hline Pde & Plagiothecium denticulatum & & & & + \\
\hline Pne & Poa nemoralis & + & & & \\
\hline Pmu & Polygonatum multiflorum & & & & + \\
\hline Pfo & Polytrichastrum formosum & & + & & \\
\hline Pst & Potentilla sterilis & & & + & \\
\hline Paq & Pteridium aquilinum & & + & & \\
\hline Rsq & Rhytidiadelphus squarrosus & & & + & \\
\hline Rid & Rubus idaeus & & & & + \\
\hline Rac & Ruscus aculeatus & & & & + \\
\hline Sgr & Stellaria graminea & & & & + \\
\hline Sne & Stellaria nemorum & & & & + \\
\hline Tba & Taxus baccata & & & & + \\
\hline Tta & Thuidium tamariscinum & & + & & \\
\hline Tpl & Tilia platyphyllos & & & + & \\
\hline Udi & Urtica dioica & & & + & \\
\hline Vmo & Veronica montana & + & & & \\
\hline Vre & Viola reichenbachiana & + & & & \\
\hline Vri & Viola riviniana & & & & + \\
\hline
\end{tabular}


Table 3. Pearson correlation coefficients between additional (passive) variables and the first three axes of PCA on plant species (see graphical representation in Figures 1 and 3 )

\begin{tabular}{lrrr}
\hline & F1 & F2 & F3 \\
\hline Species richness & 0.19 & -0.42 & -0.13 \\
Vascular richness & 0.26 & -0.44 & -0.07 \\
Moss richness & -0.21 & -0.08 & -0.30 \\
Ellenberg's Light Index & -0.39 & 0.22 & 0.06 \\
Ellenberg's Wetness Index & 0.22 & 0.13 & -0.06 \\
Ellenberg's pH Index & 0.38 & -0.41 & 0.06 \\
Ellenberg's Fertility Index & 0.37 & -0.41 & 0.06 \\
Humus Index & -0.29 & 0.29 & -0.11 \\
Total canopy cover & 0.20 & 0.24 & -0.04 \\
Hornbeal canopy cover & 0.29 & -0.12 & -0.08 \\
Beech canopy cover & 0.15 & 0.24 & -0.04 \\
Total subcanopy cover & 0.13 & -0.18 & -0.22 \\
Hornbeam subcanopy cover & 0.19 & -0.19 & -0.14 \\
Beech subcanopy cover & 0.06 & -0.11 & -0.19 \\
Undisturbed ground cover & 0.10 & 0.09 & -0.26 \\
Weak disturbance ground cover & -0.17 & -0.15 & 0.30 \\
Severe disturbance ground cover & -0.01 & -0.01 & 0.12 \\
\hline
\end{tabular}


Table 4. Floristic heterogeneity in the six studied forests and in two beech communities. See text for calculation details. $\mathrm{EF}=$ Endymio-Fagetum. IF = llicio-Fagetum

\begin{tabular}{lrr}
\hline & EF & IF \\
\hline Compiègne & 17.4 & 0.6 \\
Eawy & 1.6 & 1.8 \\
Retz & 37.6 & 6.7 \\
Brotonne & 2.8 & 17.7 \\
Lyons & 11.9 & 1.0 \\
\hline
\end{tabular}


Table 5. Relationship between Humus Index and several community indices in the five studied forests. Signed Mantel test, product-moment correlation coefficient: *** $=\mathrm{P}<0.001$

\begin{tabular}{|c|c|c|c|c|c|}
\hline & Compiègne & Eawy & Retz & Brotonne & Lyons \\
\hline Vascular richness & $-0.56^{\star \star \star}$ & $-0.15^{\star \star \star}$ & $-0.50^{\star \star \star}$ & $-0.52^{\star \star \star}$ & $-0.33^{\star \star \star}$ \\
\hline Moss richness & $0.31^{\star \star *}$ & $0.09^{* * *}$ & $0.30^{\star \star \star}$ & $0.29^{\star \star *}$ & $0.28^{* * *}$ \\
\hline pH Index & $-0.50^{\star \star \star}$ & $-0.14^{\star \star \star}$ & $-0.68^{\star \star \star}$ & $-0.32^{\star \star \star}$ & $-0.45^{\star \star \star}$ \\
\hline Fertility Index & $-0.46^{\star \star \star}$ & $-0.12^{\star \star \star}$ & $-0.53^{\star \star \star}$ & $-0.24^{\star \star \star}$ & $-0.43^{\star \star \star}$ \\
\hline Light Index & $0.29^{\star \star \star}$ & $-0.05^{\star \star \star}$ & $0.56^{\star \star \star}$ & $0.19^{\star \star \star}$ & $0.19^{* \star *}$ \\
\hline Wetness Index & $-0.13^{\star \star *}$ & $-0.25^{\star \star \star}$ & $0.06^{\star \star \star}$ & $-0.12^{\star * \star}$ & $-0.22^{* \star *}$ \\
\hline A group cover & $-0.36^{\star \star \star}$ & $-0.33^{\star \star \star}$ & $-0.65^{\star \star \star}$ & $-0.23^{\star \star \star}$ & $-0.27^{\star \star \star}$ \\
\hline B group cover & $0.28^{* * *}$ & $0.11^{* * *}$ & $0.50^{\star \star \star}$ & $0.09^{\star \star *}$ & $0.26^{\star * *}$ \\
\hline C group cover & $-0.39^{\star \star *}$ & $-0.13^{\star \star \star}$ & $-0.11^{\star \star *}$ & $-0.29^{\star \star \star}$ & $-0.14^{\star \star \star}$ \\
\hline D group cover & $-0.07^{\star * *}$ & $-0.11^{\star \star \star}$ & $-0.51^{\star \star *}$ & $-0.41^{\star \star *}$ & $-0.15^{\star \star \star}$ \\
\hline
\end{tabular}


Appendix 1 . List of plant species used in data analysis (species present in more than 10 samples). Vascular species names in roman, moss
species names in italic type Code Latin name L Light Index Wetness Index $\quad \mathrm{pH}$ Index Fertility Index Number of samples

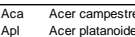

$\begin{array}{ll}\text { Aps } & \text { Acer pseudoplatanus } L \text {. } \\ \text { Acy } & \text { Aethusa cynapium L. }\end{array}$

AcS Agrostis capillaris $L$

$\begin{array}{ll}\text { Ast } & \text { Agrostis stolonifera } \\ \text { Are } & \text { Aiuga reptans L. }\end{array}$

$\begin{array}{ll}\text { Are } & \text { Ajuga reptans } L \text {. } \\ \text { Ape } & \text { Alliaria petiolata (Bieb.) Cavara \& Grande }\end{array}$

Ane Anemone nemoros $L$

Anum maculatum $L$.

Athyrum fili-femina (L.) Roth
Atrichum undulatum (Hedw.) P. Beauv

Betula pendula Roth

Blechnum spicant (L.) Roth

m sylvaticum (Huds.) Beaus

Brachythecium rutabulum (Hed)
Bromus erectus Huds.

$\begin{array}{ll}\text { Ber } & \text { Bromus ere } \\ \text { Cep } & \text { Calamagros } \\ \text { Csp } & \text { Callitriche sp } \\ & \text { Clats }\end{array}$

Callitiche sp.
$\mathrm{cu}$ Calluna vilgaris (L.) Hull

Cardanine flexuosa With.

Carex ovalis Good.

Carex pendula Huds.

Carex pilulitera L.

Carex sylvatica Hus

Caspinus bettulus $L$ :

Circaea Iutetiana $L$
Conopodium maius

Crataegus monogyna Jace
Cytisus scoparius (L.) Link

Dactylis glomerata $L$.

Deschampsia cespitosa (L.). Beauv

Dicranella heteromalla (Hedw.) Sch

Dicranum scoparium Hed

Dryopteris carthusania (Villar) H.P.Fuch

Dryopteris dilatata (Hoffm.) A.Gray
Dryopteris filix-mas (L.) Schoott

Epilobium angustitiolium $L$
Epilobium montanum $L$

Eupatorium cannabinum $L$.

Fagus sylvatica $L$.

Festuca gigantea (L.) Vill.
Festuca heterophylla Lam.

Fragaria vesca

Frangula dodonei Ard.
Graxinus excelsior L.
Gaopsis tetrahit L. agg.

Galium aparine $L$.
G.) Scop.

Galium saxatile $L$. Geranium robertianum $L$.

Glechoma hederacea $L$

Hedera helix L.

Holcus mollis $L$

Hyacynthoides non-sciricum perforatum $L$

Hypnum cupressiforme Hedw.

Hypnum Jullandicum Holmen \& Wamcre

Isothecium myosuroides Brid.

Juncus effusus $L$.

Lamium galeobdolon (L) Crantz aga

Lapsana communis $L$.

Lonicera periclymenum $L$.
Lotus pedunculatus Cav.

Luzula forsteri (Sm.) DC.
Luzula multifiora (Retz)

Luzula pilosa (L.) Willd.

Lysimachia nemorum $L$

Melampyrum pratense

Melica uniffora Retz.
Mercurialis perennis $L$

Milium effusum $L$ L.
Mnium hornum Hed

Moehringia trinernia (L.) Clair
Molinia caerulea (L.) Moench

Oxalis acetosella $L$.

Pinus sylvestris $L$.

Plagiothecium dentium (Hedw.) T.Kop.

Poa nemoralis $L$.

Poa trivalis $L$.
Polygonatum multiflorum (L.) A

Polygonum hydropiper $L$.) A.

Polytrichastrum formosum (Hedw.) G.L.Sm

Prunus avium $L$.
Prunus serotina Eh

Pseudocleropodium purum (Hedw.) Fleisch. Ex Broth.

Quercus petraea (Mattus.) Lieb.

Quercus robur $L$.

Ranunculus repens $L$.
Rhytidiadelohus squarrosus (Hedw.) Warns.

Rntiadelonus squarosus (Hedw.) Wanst.

Rosa canina $L$.

Rubus idaeus $L$. $L$

Ruscus aculeatus $L$.
Salix caprea $L$.

Sambucus nigra $L$.

Scrophularia nodosas $L$.
Sorbus aucuparia $L$.

Sorbus aucuparia

Stachys sylvatica L

Stellaria holostea $L$.

Stellaria nemoru $L$.
Taxus baccata $L$

Teucrium scorodonia $L$.

Thuidium tamarisciin
Tilia platyphyllos So

Urtica dioica L.

Vaccinium myrtillus $L$.

Veronica mont
Vicia sepium $L$.

Viola reichenbaachiana Jord
Viola riviniana Reichb. 
Appendix 2. List of environmental variables measured in each vegetation sample and used in data analysis

\begin{tabular}{|c|c|}
\hline Code & Environmental variable \\
\hline Cov 1 & Hornbeam canopy cover \\
\hline Cov 2 & Beech canopy cover \\
\hline Cov 3 & Sessile oak canopy cover \\
\hline Cov 4 & Pedunculate oak canopy cover \\
\hline Cov 5 & Hornbeam subcanopy cover \\
\hline Cov 6 & Beech subcanopy cover \\
\hline Cov 7 & Pedunculate oak subcanopy cover \\
\hline Cov 8 & Hornbeam tall shrub cover \\
\hline Cov 9 & Beech tall shrub cover \\
\hline Cov 10 & Sycamore tall shrub cover \\
\hline Cov 11 & Hornbeam shrub cover \\
\hline Cov 12 & Hawthorn shrub cover \\
\hline Cov 13 & Beech shrub cover \\
\hline Cov 14 & Holly shrub cover \\
\hline Cov 15 & Black cherry shrub cover \\
\hline Cov 16 & Pedunculate oak shrub cover \\
\hline H.I. & Humus Index \\
\hline Surf 1 & No topsoil disturbance \\
\hline Surf 2 & Boulder or drain \\
\hline Surf 3 & Litter undisplaced but traces of engine trail \\
\hline Surf 4 & Litter undisplaced, traces of engine trail and slash remains \\
\hline Surf 5 & Litter displaced, organic sol intact \\
\hline Surf 6 & Soil packing, litter displaced, traces of engine trails \\
\hline Surf 7 & Litter mixed with organic soil \\
\hline Surf 8 & Soil deposited above litter \\
\hline Surf 9 & Organic soil displaced, exposing the mineral soil \\
\hline Surf 10 & Engine trail packed and managed \\
\hline Surf 11 & Soil mixed with litter \\
\hline Surf 12 & Rut 5-15 cm deep \\
\hline Surf 13 & Rut $16-30 \mathrm{~cm}$ deep \\
\hline Surf 14 & Mineral soil visible at the bottom of ruts \\
\hline Surf 15 & Fallen branchwood less than $10 \mathrm{~cm}$ diameter \\
\hline Surf 16 & Fallen branchwood $10-30 \mathrm{~cm}$ diameter \\
\hline Surf 17 & Fallen branchwood more than $30 \mathrm{~cm}$ diameter \\
\hline Surf 18 & Fallen trunkwood \\
\hline Surf 19 & Stump \\
\hline Surf 20 & Stump with slash remains \\
\hline Stem & Stem density \\
\hline BA & Basal area \\
\hline Age & Age of dominant trees \\
\hline
\end{tabular}

